\title{
The bubbles or the boiling pot? An ecosystemic approach to culture, environment and quality of life
}

\author{
André Francisco Pilon
}

Received: 10 October 2007/ Accepted: 26 February 2008

(C) Springer-Verlag 2008

\begin{abstract}
For the diagnosis and prognosis of the problems of quality of life, a multidisciplinary ecosystemic approach encompasses four dimensions of being-in-theworld, as donors and recipients: intimate, interactive, social and biophysical. Social, cultural and environmental vulnerabilities are understood and dealt with, in different circumstances of space and time, as the conjugated effect of all dimensions of being-in-the-world, as they induce the events (deficits and assets), cope with consequences (desired or undesired) and contribute for change. Instead of fragmented and reduced representations of reality, diagnosis and prognosis of cultural, educational, environmental and health problems considers the connections (assets) and ruptures (deficits) between the different dimensions, providing a planning model to develop and evaluate research, teaching programmes, public policies and field projects. The methodology is participatory, experiential and reflexive; heuristic-hermeneutic processes unveil cultural and epistemic paradigms that orient subject-object relationships; giving people the opportunity to reflect on their own realities, engage in new experiences and find new ways to live better in a better world. The proposal is a creative model for thought and practice, providing many opportunities for discussion, debate and development of holistic projects integrating different scientific domains (social sciences, psychology, education, philosophy, etc.).
\end{abstract}

Electronic supplementary material The online version of this article (doi:10.1007/s00254-008-1272-6) contains supplementary material, which is available to authorized users.

A. F. Pilon $(\bowtie)$

School of Public Health,

University of São Paulo,

São Paulo, Brazil

e-mail: gaiarine@usp.br
Keywords Education - Culture - Politics - Society · Health · Environment

\section{The salary of God and the work of man}

In the beginning, God created the heavens and the earth. Relying in the excellence of his work, he expected that sentient beings, like mankind, would, in due time, bring him heavenly dividends, acknowledging the prominence of his creation, preserving its dynamic equilibrium and enhancing it with beauty, love and care.

Since then the universe has been continuously unfolding: galaxies gave birth to stars, stars diligently assembled the elements to build an infinity of planets, which eventually could harbour life; in the Earth, plants garnished it with flowers and replenished it with fruits, animals spread over the land and the sea, birds excelled with their beautiful feathers and songs.

As a conscious and animate partner of God, mankind should honour God's expectations, bestowing a significant contribution to his endeavour. Respect for the diversity of life and scenaries, law-abiding and ethical behaviour, care for others, equity and justice would be God's payment in recognisance for his endeavour.

Would God be satisfied with mankind's partnership in his glorious creation?

Nowadays, quality of life, natural and man-made environments, physical, social and mental well-being are undermined by all sorts of hazards and injuries; political, economical and social disarray normalise atrocious behaviours and violence, dehumanisation, depersonalisation and reification erode quality of life all over the world.

Although many problems may not be internally soluble within the human community, which is not self-enclosed 
and has a relationship to the sky, to the gods, to the nature, to strange forces that we cannot control (Wood 2000), current events on Earth confirm the strong link between individuals, groups, society and the environment.

The future of creation, "new Earth and new Heavens", would depend on the quality of the relationships between men and men and men and nature. "The subject matter of ecology is not individual organisms but interrelationships, the science from its beginning drew heavily upon concepts, models, and metaphors from other fields, within and outside the sciences" (Cittadino 2002).

The application of ecological systems theory to human development shows that the myth of power and the resulting conflicts (man versus environment, nations versus nations, classes versus classes, man versus God) ignores the fact that in cybernetic systems the parts can not take unilateral control over the whole or any other part (Bateson 1979)

The world is not classifiable in different kinds of objects, but in different kinds of connections (Capra 2002; Heisenberg 1958); it can be thought as a kind of a giant hologram, in which, in some implicit sense, a total order is contained in each region of space and time (Shainberg in Hiley and Peat 1994). Inwardness and outwardness are complementary aspects of reality.

The micro, meso and macrosystems are complex "layers" of the environment structure, each having an effect on the human development (Bronfenbrenner 2004). Selfhood, embodiment and environment are extensions of each other, microcosmic "bodies" are continuous with and permeated by the macrocosmic "environment".

The polymeric structure of space-time pervades the entire universe, thousands of historical events closely interrelate in the genesis of all events (phenomena, processes, actions); the higher is the numbers of levels in the system under research, the more complicated is the polymeric structure of the actual part of the time's metabolic space (Lisin and Platonenko 2005/2006).

According to a phenomenological approach (Binswanger 1957), being-in-the-world (Lebenswelt), encompasses the "inner world" (Eingenwelt), the "interactive world" (Mitwelt), the "world of men" (Menschenwelt) and the "environment" (Umwelt). Existence should be understood as the focal point of these overlapping "worlds".

Three overlapping spheres co-exist: the ecosphere, relating to a person's (or groups') physical environment and surroundings, the sociosphere, relating to an individual's net interactions with all other people in an environment and the technosphere, encompassing all the person-made things in the world (Gardiner in Goumain 1989).

A mysterious tissue or matrix underlies and gives rise to both the perceiver and the perceived. The environment presupposes perceptions and vital processes, it pre-exists and co-exists (Wirklichkeit), it integrates our experience in the daily life (Lebenswelt), it is also a concept, a result of a conscious process (Realität), a domain of "scientific knowledge" (Wallner and Peschl in Cohen 1999).

It is not the efficient exploitation of knowledge that matters, but the learning process by which it is created. Due to non-linear relationships, small inputs in systems that are far from equilibrium can trigger massive consequences, as posited by evolutionary thermodynamics, in terms of self-organising systems and sustainable development (Prigogine 1980).

Knowledge cannot be identified with the ontological reality, it serves the organisation of the experiential world and should be actively built up (Allen 2004). The relationship between sustainable development and economic growth has been over-emphasised; social justice, solidarity and respect for ecological limits have been neglected (Verburg and Wiegel 1997).

Complex thought has an ethical dimension (Morin 2004). The unfolding cosmos, as an autopoietic process, needs a general extended view, a real world's theory connected to the different states of knowledge of the different scientific disciplines, from which special extended views could be deduced (Kofler 2007), in view of the different problems currently posed.

Sustainability cannot be pursued within the prevailing development strategies, which ignore, underestimate and undermine values and environments essential to a healthy human development. Security, sustainability and stability depend on an ethical and spiritual world view, on respectful and enriching values sustained within a specific society (Ryan 1995).

Growth, power, wealth, work and freedom must acquire new meanings (O' Sullivan 1987). Foreign policy, education, politics, economics, health and social welfare must change their current paradigms and practices, building a culture of peace, environment sustainability, non-violence, justice and cooperation as organising principles.

The future of creation, "new Earth and new Heavens", would depend on the quality of the relationships between men and men and men and nature. Processes and products, principles and actions are each other mirror and should walk together; duties and rights, deeds and beliefs are the faces of the same coin; inside and outside complement each other.

\section{The need for new policies to live better in a new world}

Nowadays, natural and built environments are destroyed, human values that took centuries to develop are annihilated by overspread violence and greedy, the essence of the 
problems is distorted by segmented public policies, academic formats, mass-media headlines, common sense prejudices and overwhelming market-place's interests.

Ethical questions, the conceptual direction and the moral legitimacy of development strategies should be examined, specially by the leaders of academic sectors, which, in the name of a "high status knowledge", have surrendered to specialisation and fragmentation, in a milieu of ethical indifference, moral objectivity and neutralism (Bowers 2006).

Sweeping market-oriented reforms, privatisations, deregulations, resulted in relinquishing state's duties to the private sector (security, health, education); public services barely survive, the "philosophical" questions of ethical, moral and civic education are left aside, in the name of information and communication technologies, presented as a panacea.

Notwithstanding the pervasiveness of marketing in society (Ait-ouyahia and Seaman 2006), we should not take current prospects for granted, projecting into the future the trends of today (exploratory forecast), but define new goals and explore new paths to reach them (normative forecast) (Jungk 1974), in view of new forms of being-in-the-world.

Public policies should not be ready-made "patches" put on bad situations to make them "straight", Instead of "mending" individual or social "defects", by focusing on needs, deficiencies and problems, they should be assetbased, internally focused and relationship driven, centered on inner resources and capacities' development (Kretzmann and McKnight 1993).

Instead of picking the "bubbles" of the surface (segmented issues), subverting or ignoring what is inside the "boiling pot" (the real problems) (Figs. 1, 2), public policies should pay attention to the relevant factors that are generating the evils of our times, encompassing governance, justice, equity, ethics and social responsibility.

The world's generalised problems can not be sorted out by segmented projects, which ignores micro, meso and macro relationships. Foreign policy, education, politics, economics, should change their current paradigms and practices, in view of a culture of peace, environmental sustainability, justice and cooperation as organising principles (Peace Alliance Foundation 2005).

Core beliefs and values, faith and trust, safety and security should be restored ("social capital"). Historic evidence indicates that significant community development takes place only when local community people are committed to investing themselves and their resources in the effort for community involvement and education (Helliwell and Putnam 2004).

When powerful political and economical groups abuse rational arguments to conceal embedded interests, new technologies usually exacerbate the gap between the

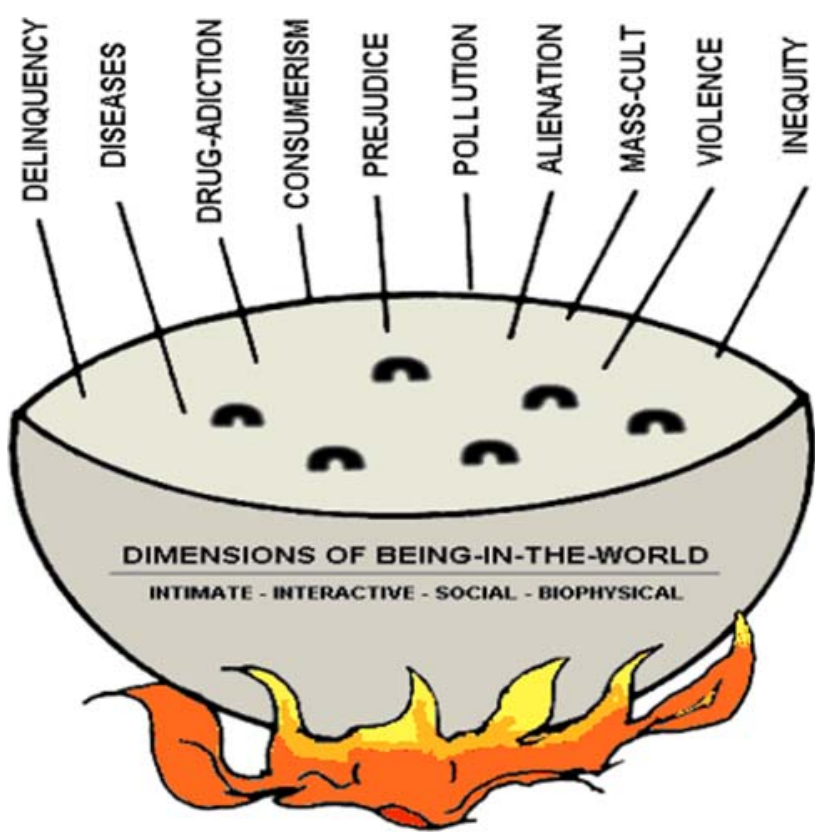

Fig. 1 Problems should be looked for deep inside the boiling pot, not in the bubbles of its surface

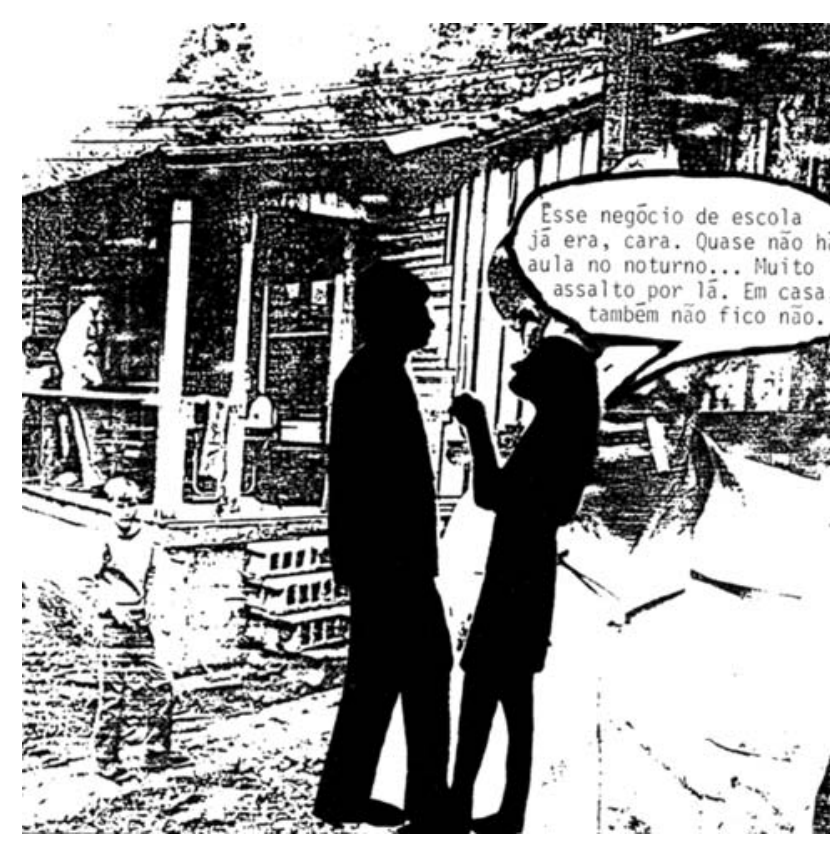

Fig. 2 Microcosmic "bodies" are continuous with and permeated by the macrocosmic "environment"

possessed and the destitute, who are continuously manipulated by propaganda to acquire all kind of gadgets, as a substitute for the lack of education, culture, justice and citizenship.

In this context, new technological waves will not rescue a devastated environment nor relieve the excluded (Mooney and Hope 2006). When political, economical and cultural disarray normalises all sorts of unethical 
procedures and transgressions, inequities, violence and atrocious behaviour are condoned and looked upon by people as part of their daily life.

Globalisation has brought violence, uprootings, displacements, discordances, war, genocide, hunger, inequities, ecological vulnerability and deep social division (American Anthropological Association 2005). More and more it becomes difficult to distinguish between "legal" and "illegal" strategies and methods, which become very much alike in the assemblage of political and economical interests.

Excepting contractual bonds, neoliberalism atomises society and breaks potential networks of solidarity (Rapley 2003). Private authority erodes state's power and the utopia of global governance, leaving it in the hands of multinational corporations, financial institutions and organised crime (Hall and Biersteker 2003).

A profound change in the present ways of being-in-theworld is imperative. In a cultural, social and environmental degenerated condition, distinction between self-interest and mankind survival is crucial, social vulnerabilities can not be disassociated from environmental, economical, political, cultural and ethical considerations.

A culture grounded on market economics tends to produce human beings who have trouble being moral and developing coherent selves (Riker 2006). Most of the megacities of the world are deeply troubled places: economies sputter, social ties weaken, political power fades. Crime and violence, joblessness, homelessness, gangs and drugs proliferate (Kretzmann and McKnight 1993).

Many cities of the so-called emergent world are recognised as problem-ridden, economically unequal and intrinsically violent ${ }^{1}$ While the elite enjoy life in fortified enclaves, most of the city dwellers live in makeshift slum housing, often without access to the basic social services (health, education) and dependent on criminality for survival.

The link between environmental stress and violence has been verified in different studies (Homer-Dixon 2006), with severe consequences. It is not a surprise that social unrest has been increasing exponentially, specially among those that immigrated to the large cities in search of a better life and are hampered by multiple obstacles.

The social vulnerabilities, that affect the poorest people in many cities of the world, has a cascade effect on the entire population. Chronic deficiencies in education, security, sanitation, dwelling, transport sway over all the

\footnotetext{
${ }_{1}^{1}$ Increasing urban sprawl and related environmental degradation; car-dependent communities, longer commutes to work; traffic gridlock, poor air quality and loss of green space, a suburban monoculture that lacks diversity; increased air pollution and sedentary lifestyles ask for a revolution that demands a long-term commitment (Caplan 2006).
}

inhabitants ${ }^{2}$; due to the outspread violence, most people become, by and large, uninvolved in civic life (Baiocchi 2005).

"Social inclusion" policies only accommodate people to the prevailing order, they do not empower them (Labonte 2004); once "included", a new wave of "egocentric producers and consumers" (Chermayeff and Tzonis 1971) will reproduce the very system responsible for their former exclusion, abusing cultural values and nature in the name of "progress" (Tsipko 1985).

Progressive social change groups must incorporate a deeper spiritual understanding into their work (Lerner 2007). Contrary to the adversary paradigm, the mutuality paradigm is based on the assumption that the other is a friend, a colleague and an ally (Fellman 1998). Protecting relationships is often overlooked, when learning is abstract and decontextualised (Konai 2005).

Besides economical and political equity, human rights include cultural and spiritual values, the preservation of rich natural and man-made environments, the engendering of beauty, creativity, conviviality, privacy, tranquillity and peace. Social and economical advancement should not be a private question, but a collective one.

Peace building, acceptance of ethical norms requires a multitude of ethically interpreted and ordered social experiences, a capacity for having morally relevant interests as the bases of rights-bearing, a broad, universally rationalised cultural knowledge, an empathy with people, including those regarded as alien, or even hostile (Znaniecki 1935).

Facade democracies usually try to repair "bad" situations to make them "straight", ignoring that "duties" and "rights" can not be prescribed in adverse political, economical, social and cultural conditions: it is a non sense to prescribe that everybody has a "right to play a piano" when the piano is not available, when no one knows how.

Freedom for is not the same as freedom from (Fromm 1941): authentic freedom or freedom for presupposes existential control, a capacity to make adequate choices; the latter merely indicates the absence of exterior constraints, the former requires an ethical ground, preparedness (there is no "freedom" for playing a piano when one lacks the ability).

Freedom and responsibility are sides of the same coin: being accountable for one another (even for other's faults, if one fails to intervene), doing or abstaining from something in view of others, are essential to authentic freedom (Levinas 1974). In a society with any organising principle at all, individual rights suppose the assumption of collective responsibilities.

\footnotetext{
${ }^{2}$ Indicators like age, income, employment, household, health status, gender, ethnic origin, perception of risks and education are the counterpart of the degree of government preparedness and capabilities to face the impact of social and natural hazards (Dwyer et al. 2004).
} 
Fig. 3 Man as a supportive species (primitive societies) versus man as a dominant species (civilised societies)

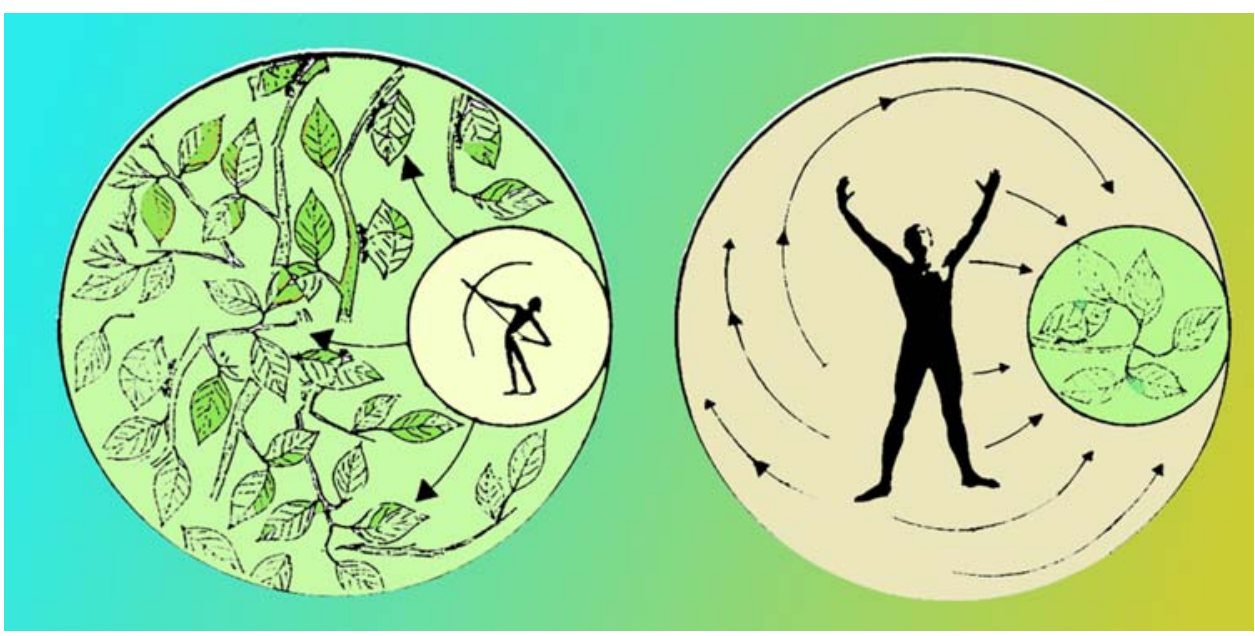

Life should acquire a new kind of normality, not by repairing humans, but by enhancing them (Miah 2003). In a cultural, social and environmental degenerated condition, "repairing" means the tentative to restate a former "normal" level of functioning, "enhancing" creates new physical, social and mental environments, which are essential to live better in a better world.

\section{The ecosystemic approach to quality of life}

To understand and resolve our present crisis, the concept of man as a "dominant" species should be reversed by man as a supportive one (Fig. 3); the identification of "progress" with individual or corporate self-interest and the way human beings deal with each other must be changed (Bookchin 1993), in view of a new political vision to govern the world.

A process of change is not a matter of throwing out "old things", nor acquiring "new things", but the development of a new way for being-in-the-world, which asks for both design and action; it is useless to change the furniture in a room without a new concept for living in it, before erecting a house, an architect looks for the well-being of the dwellers.

The objective is not to solve taken for granted problems (the "bubbles" in the surface), but to unveil and work with the dynamic and complex configurations in the "boiling pot", encompassing the mutual role of individuals, groups, society and environment to understand how problems arise and how to deal with them, at micro, meso and macro level.

Instead of "repairing" "bad" situations to make them "straight", problems of difficult settlement or solution should be assessed in different contexts and settings, as expressions of the interplay of the dynamic configurations encompassing the different dimensions of being-in-the- world: intimate, interactive, social and biophysical (Pilon 2003).

The four dimensions must be dealt with simultaneously, as mutually entangled donors and recipients, considering their connections and ruptures and how actual and potential deficits and defaults affect each other, as they induce the events (deficits and assets), cope with effects (desired or undesired) and contribute for change (expected outcomes):

- intimate dimension: core beliefs and values, coping abilities (cognitive, affective and cultural), self-esteem, resilience, civic profile, capabilities, expectations, desires, existential control;

- interactive dimension: networks, communities, groups' cohesion and mutual support (family, neighbourhood, workplace, religious and political affiliations), friendship ties;

- social dimension: public policies, educational, cultural, public health and socio-economic status, local, national and global citizenship, partnerships and resources; civic engagement;

- biophysical dimension: biological endowment, matter and energy, fauna, flora, land, water, air, natural and man-made environments, scenarios, landscapes, buildings, artefacts.

In an ecosystemic model of culture, there is a dynamic equilibrium, interconnection, interaction and reciprocity between the different dimensions of the world (Table 1). In a non-ecosystemic model, they drift apart or seek a hegemony (individuals, groups, societies and environment are in conflict); disruption, isolation, unbalances, catastrophes, disease, famine and violence follow soon (Table 2).

Analysis implies the assessment of the actual and potential role of each dimension in view of the configurations formed by the imbrication of the different dimensions in the space-time continuum (Fig. 4); in this sense, overall 
Table 1 Dimensions' equilibrium in the ecosystemic model of culture

\begin{tabular}{lllll}
\hline Recipients & Donors & & & \\
\cline { 2 - 5 } & Intimate & Interactive & Social & Biophysical \\
\hline Intimate & Creativeness & Support & Services & Vitality \\
Interactive & Cooperation & Cohesiveness & Diversity & Niches \\
Social & Citizenship & Partnerships & Organisation & Spaces \\
Biophysical & Care & Preservation & Sustainment & Equilibrium \\
\hline
\end{tabular}

Table 2 Dimensions' disruptions in the non-ecosystemic model of culture

\begin{tabular}{lllll}
\hline Victims & Inflictors & & & \\
\cline { 2 - 5 } & Intimate & Interactive & Social & Biophysical \\
\hline Intimate & Solypsism & Abdication & Domination & Agression \\
Interactive & Heteronomy & Fanaticism & Cooptation & Dispersion \\
Social & Subjection & Corporativism & Totalitarian & Extinction \\
Biophysical & Predatory & Exploitation & Spoliation & Savageness \\
\hline
\end{tabular}

\begin{tabular}{|c|c|c|c|c|}
\hline & INTIMATE & INTERACTIVE & SOCIAL & BIOPHYSICAL \\
\hline $\begin{array}{l}\text { DIAGNOSIS } \\
\text { OF THE } \\
\text { EVENTS }\end{array}$ & $\begin{array}{c}\text { SUBJECTS' } \\
\text { COGNITIVEAND } \\
\text { AFFECTIVE } \\
\text { ACTUALSTATUS } \\
\end{array}$ & $\begin{array}{l}\text { GROUPS 'AND } \\
\text { COMMUNITIES' } \\
\text { DYNAMICS } \\
\text { AND COHESION }\end{array}$ & $\begin{array}{l}\text { PUBLIC POLICIES } \\
\text { LAW ENACTMENT } \\
\text { CITIZENSHIP } \\
\text { PARTICIPATION }\end{array}$ & $\begin{array}{l}\text { NATURALAND } \\
\text { MAN-MADE } \\
\text { ENVIRONMENTS } \\
\text { BEINGS, THINGS }\end{array}$ \\
\hline $\begin{array}{l}\text { ELICITING } \\
\text { NEW } \\
\text { EVENTS }\end{array}$ & $\begin{array}{l}\text { DEVELOPMENT } \\
\text { OF SUBJECTS' } \\
\text { EXISTENTIAL } \\
\text { SELF-CONIROL }\end{array}$ & $\begin{array}{c}\text { DEVELOPMENT } \\
\text { OF GROUPS AND } \\
\text { PRO-ACTIVE } \\
\text { COMMUNITIES } \\
\end{array}$ & $\begin{array}{l}\text { DEVELOPMENT } \\
\text { OF PUBLIC } \\
\text { POLICIES AND } \\
\text { CITIZENSHIP }\end{array}$ & $\begin{array}{c}\text { PROMOTION OF } \\
\text { NATURAL AND } \\
\text { MANMADE } \\
\text { ENVIRONMENTS }\end{array}$ \\
\hline $\begin{array}{c}\text { IMPACT } \\
\text { ON EACH } \\
\text { DIMENSION }\end{array}$ & $\begin{array}{l}\text { ENHANCEMENT } \\
\text { OF SUBJECTS' } \\
\text { WELL-BEING }\end{array}$ & $\begin{array}{l}\text { ENHANCEMENT } \\
\text { OF GROUPS AND } \\
\text { COMMUNITIES }\end{array}$ & $\begin{array}{l}\text { ENHANCEMENT } \\
\text { OF POLICIES AND } \\
\text { CITIZENSHIP }\end{array}$ & $\begin{array}{l}\text { ENHANCEMENT } \\
\text { OF OVERALL } \\
\text { ENVIRONMENT }\end{array}$ \\
\hline
\end{tabular}

Fig. 4 Imbrication of the four dimensions of the world in the genesis and treatment of the problems

policies and projects, in different domains (well fare, education, health, environment, etc.) should:

- define the problems within the "boiling pot" instead of reducing them to the bubbles of the surface (fragmented, taken for granted problems);

- deal with the events as products of a dynamic field, intertwining the four dimensions of being-in-the-world: intimate, interactive, social and biophysical (see Table 3 for health-related problems);

- verify the deficits and assets of the dimensions as donors and recipients, in view of their relationships, in a mutually entangled web (configurations);

- revive the singularity (identity, proper characteristics) of and solidarity (reciprocity, mutual support) between all dimensions, strengthening connections and sealing ruptures.

- consider the development of an ecosystemic model of culture, in terms of the balance between all the dimensions of the world (opposite to the current nonecosystemic model).

\section{The work in the socio-cultural learning niches}

Experiential, collaborative, innovative and socially beneficial projects should develop in the socio-cultural learning niches a network of hope, dignity and self-reliance: individuals who think critically, communicate effectively, value diversity, act ethically and show an empathy with people, including those regarded as alien, or even hostile.

Different fronts and actors should be involved, encompassing research and teaching programmes, development of public policies, mass-media communication, governmental and non-governmental organisations, lay and religious leaderships, community building advocacy. How the experience is defined and dealt with is a crucial aspect in the process of change.

Working with phenomena (how reality appears in a specific space-time horizon of understanding, feeling and action), requires an adequate learning environment, which is essential to moral and democratic education (Lind 2003). The methodology in the socio-cultural learning niches should be participatory, experiential and reflexive, giving the opportunity to engage in new experiences.

Environmental and cultural degradation, climate warming, pollution and looming populations point to questions of power, status and control (Wilson 2003). A shared way of apprehending the world, the capacity to respond adequately to the experiences, encounters, engagements and interactions, depend on the alternation of challenge and support ${ }^{3}$

To develop awareness and capabilities beyond the traditional schemes of thought, feeling and action, subjective and objective realities should be entangled, encompassing the alien that we strive to understand and the familiar that we take for granted (Gadamer 1977); this creates an "excess of meaning", in view of new paradigms of knowledge and action.

Heuristic-hermeneutic experiences unveil cultural and epistemic backgrounds and subject-object relationships in a specific space-time horizon of understanding, feeling and action. Findings and contentions of the different discourses

\footnotetext{
3 "Strategic communication" implies working with people as the essential component of the change; supporting dialogue and debate instead of designing, testing and delivering messages; sensitively placing that information into the dialogue and debate instead of didactic conveying of information from technical experts; focus on social norms, policies, culture and a supportive environment instead on individual behaviours; negotiating the best way forward in a partnership process instead of persuading people to do something; people most affected by the issues of concern playing a central role instead of technical experts in 'outside' agencies dominating and guiding the process (Rockefeller Foundation 1974).
} 
Table 3 Effects of the dimensions of the world in selected health-related problems

\begin{tabular}{|c|c|c|c|c|}
\hline $\begin{array}{l}\text { Health related } \\
\text { problems }\end{array}$ & $\begin{array}{l}\text { Intimate subjective } \\
\text { well-being }\end{array}$ & $\begin{array}{l}\text { Interactive group } \\
\text { development }\end{array}$ & $\begin{array}{l}\text { Social collective } \\
\text { well-fare }\end{array}$ & $\begin{array}{l}\text { Biophysical environment } \\
\text { and beings }\end{array}$ \\
\hline Depression (exogenous) & $\begin{array}{l}\text { Quality of own } \\
\text { project of life }\end{array}$ & $\begin{array}{l}\text { Group support social binds } \\
\text { inclusion }\end{array}$ & $\begin{array}{l}\text { Social and cultural } \\
\text { opportunities }\end{array}$ & $\begin{array}{l}\text { Environmental conditions } \\
\text { surroundings }\end{array}$ \\
\hline $\begin{array}{l}\text { Sexually transmitted } \\
\text { diseases }\end{array}$ & $\begin{array}{l}\text { Existential control } \\
\text { self-esteem }\end{array}$ & $\begin{array}{l}\text { Peers' values fidelity } \\
\text { defidence }\end{array}$ & $\begin{array}{l}\text { Social awareness public } \\
\text { policies }\end{array}$ & Physical protection (preservative) \\
\hline Adolescent pregnancy & $\begin{array}{l}\text { Emotional maturity } \\
\text { self-esteem }\end{array}$ & $\begin{array}{l}\text { Family cohesion group } \\
\text { values }\end{array}$ & Revenue schooling health & Quality of life spaces settlements \\
\hline Violence drug-addiction & $\begin{array}{l}\text { Emotional balance } \\
\text { resiliency }\end{array}$ & $\begin{array}{l}\text { Sub-cultures leadership } \\
\text { group values }\end{array}$ & Cultural models inclusion & Quality of dwellings settlements \\
\hline
\end{tabular}

provide the basis for analysis of consensus or discrepancies, agreements or disagreements, in view of a new ground for assumptions regarding the experience.

Innovative projects to develop the ecosystemic conditions to live better in a better world (Fig. 4), depend on collaborative experiential learning and communicating processes within the socio-cultural learning niches, of a network of hope, dignity and self-reliance, consisting of individuals who think critically, communicate effectively, value diversity and act ethically.

The objective is not to solve taken for granted problems (the "bubbles" of the surface), but to unveil and work with the dynamic and complex configurations in the "boiling pot", considering individuals, groups, society and environments as active components of the current problems. The heuristic-hermeneutic work in the socio-cultural learning niches is subsequently described:

- Unveiling subject-object relationships and contents (intimate dimension): experiences are unveiled by asking the participants to write down in a piece of paper (not identified) whatever comes to their minds in view of circumstantial images or objects previously selected to catch their eyes (like bottle caps linked by a string, passed along).

- Sharing perceptions in the group (interactive dimension): The written reports are subsequently redistributed to the participants (out of sort), who share form ${ }^{4}$ and content by reading them aloud in the group; the experience goes beyond individual initial perceptions and is enriched by crossing them in the group.

\footnotetext{
${ }^{4}$ Subject-object relationships can be analyzed in terms of different categories: Appropriation: Construction of new forms of being-in-theworld, alteration of cognitive, affective and conative paradigms. Common-sense: Conformity to established, commonplace, stereotyped ways of seeing things, without further questioning. Academic: Reduction to logical categories and frozen schemes of thought to achieve closure, classifying and describing. Dependency: Trust on exterior authority to describe and qualify own experience, alienation, bewilderment, confusion. Resistance: Resistance to being involved, failure to see any meaning in the experience. Dogmatism: Adherence to fixed paradigms and strict forms of being-in-the-world.
}

- Acting on the cultural and natural milieu (social and biophysical dimensions): Old and new forms of beingin-the-world are compared, alternative configurations are developed by new experiences in the group, cultural, social, political, economical and environmental issues are analysed in view of different systems of culture (ecosystemic or non-ecosystemic).

- Developing a new project of life: As a result of a participatory, experiential and reflexive process, the participants have the opportunity to reflect on their own realities and elaborate new forms to transform them, developing their capabilities to analyse and act upon present and future configurations (Fig. 5), formed by the interplay of the different dimensions of being-inthe-world.

\section{Conclusions}

\section{Research findings}

- How to deal with the enclosure of the cultural and environmental commons by the current fragmented public

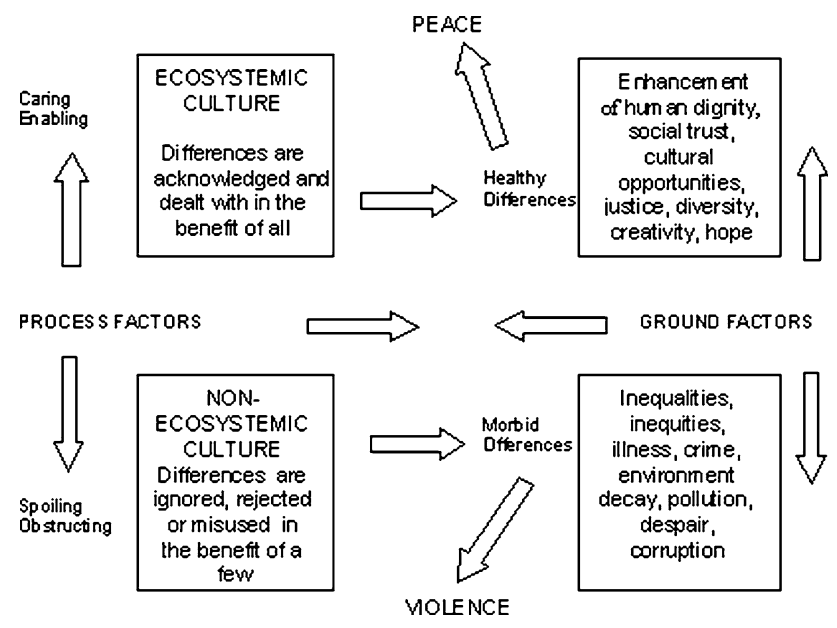

Fig. 5 Violence and peace in the ecosystemic and non-ecosystemic models of culture 
policies and reduced conceptual models, in view of an integrated multidisciplinary ecosystemic approach.

- How to work with the dynamic configurations intertwining the four dimensions of being-in-the-world and develop their singularity and reciprocity, enhancing the connections and sealing the ruptures between them.

- How to develop ethics, education, culture, natural and man-made environments, physical, social and mental well-being, as by-products of an ecosystemic model of culture, in view of acceptance, consistency, effectiveness, evidence and endurance.

\section{Policy lessons}

- Assessment, planning, development and evaluation of public policies, teaching and research projects and community programmes should encompass the four dimensions of being-in-the-world.

- The circumstances that affect individuals, groups, society, natural and man-made environments depend on each other and must be supported simultaneously in view of their singularities and mutual balance.

- Ethics, education, culture, human rights, public policies, physical, social and mental well-being, citizenship, natural and man-made environments and quality of life are strongly affected by the different models of culture (ecosystemic or non-ecosystemic).

- New paradigms of growth, power, wealth, work and freedom should be developed to face the current economic, social, political, cultural, educational and environmental turmoil.

\section{References}

Ait-ouyahia H, Seaman S (2006) Marketing needs the humanities: the case for philosophy. In: Fourth international conference on new directions in the humanities, Cartage, 2006 [online]: http://h06. cgpublisher.com/proposals/391/index_html

Allen P (2004) Models of evolutionary self-organization in social and economic systems. In: "Complexity science and the exploration of the emerging world", Workshop. The University of Texas at Austin, April 17, 2004 [online]: http://order.ph.utexas.edu/PAllen.pdf

American Anthropological Association (2005) Bringing the past into the present. In: 104th Annual Meeting, Washington

Baiocchi G (2005) The Citizens of Porto Alegre. Boston Review, March/April 2005 [online]: http://bostonreview.net/BR31.2/ baiocchi.html

Bateson G (1979) Mind and nature: a necessary unity. Ballantine Books, New York

Binswanger L (1957) Being-in-the-world. Souvenir Press, London

Bookchin M (1993) What is social ecology? In: Zimmerman ME (ed) Environmental philosophy: from animal rights to radical ecology. Prentice Hall, Englewood Cliffs

Bowers C (2006) How universities contribute to the enclosure of the cultural and environmental commons, 2006. Online: http://www. loveembodied.org/nspblog/article.php?story $=20061014185805582$
Bronfenbrenner U (2004) Making human beings human: bioecological perspectives on human development. Sage Publications, Inc, London

Capra F (2002) The hidden connections : a science for sustainable living. Harper Collins

Caplan D (2006) Creating the natural city by managing growth renew Canada May/June 2006

Chermayeff S, Tzonis A (1971) Shape of community. Realization of human potential. Penguin Books, Middlesex

Cittadino E (2002) Ecology and American social thought in ecology. In: Theology and judeo-christian environmental ethics conference, University of Notre Dame. [online]: http://www.nd. $\mathrm{edu} / \sim$ ecoltheo/abstracts_cittadino.htm

Dwyer A et al (2004) Quantifying social vulnerability: a methodology for identifying those at risk to natural hazards. Geoscience Australia Record 2004/14 [online]: http://www.ga.gov.au/ image_cache/GA4267.pdf

Fellman G (1998) Rambo and the Dalai Lama: the compulsion to win and its threat to human survival. Suny Press, Albany. Online: http://people.brandeis.edu/ fellman/intro-essay.html

Fromm E (1941) Escape from freedom. Holt, Rinehart and Winston, Inc., New York

Gadamer HG (1977) Philosophical hermeneutics. University of California Press, Berkeley

Gardiner WL (1989) Forecasting, planning, and the future of the information society. In: Goumain P (ed) High technology workplaces: Integrating technology, management, and design for productive work environments. Van Nostrand Reinhold, New York, pp 27-39

Hall RB, Biersteker TJ (2003) The emergence of private authority in global governance. Series: Cambridge studies in international relations (No. 85). Brown University, Rhode Island

Heisenberg W (1958) Physics and philosophy: the revolution in modern science. Harper and Row, New York

Helliwell JF, Putnam RD (2004) The social context of well-being. One contribution of 12 to a discussion meeting issue 'the science of wellbeing: integrating neurobiology, psychology and social science'. Philos Trans R Soc Lond B: Biol Sci 359(1449):1435-1446

Homer-Dixon TF (2006) Environment, scarcity, and violence. Princeton University Press

Kretzmann JP, McKnight JL (1993) Building communities from the inside out: a path toward finding and mobilizing a community's assets. Evanston IL: Institute for Policy Research

Jungk R (1974) Pari sur l'homme. In: Laffont R (ed) Paris

Kofler WA (2007) "General extended view" of our world as basis for "special extended views" for sectoral aspects and disciplines and an "applied extended view for sustainability". In: Abstracts of the international conference on environment: survival and sustainability-ESS2007, Nicosia, Educational Foundation of Near East University, pp 774-775

Konai H (2005) Thaman nurturing relationships: a pacific perspective of teacher education for peace and sustainable development [online]: http://www.unescobkk.org/index.php?id=3811

Labonte R (2004) Social inclusion/exclusion: dancing the dialectic. Health Promot Int 19(1):115-121

Lerner M (2007) Building a spiritual left [online]: http:// dragonflymedia.com/portal/2005/06/lerner.html

Levinas E (1974) Autrement qu'être ou au-delà de l'essence. Kluwer, Paris

Lind G (2003) The meaning and measurement of moral judgement competence revisited-a dual-aspect model. In: Fasko D, Willis W (eds) Contemporary philosophical and psychological perspectives on moral development and education. Hampton Press, Cresskill

Lisin AV, Platonenko V (2005/2006) I Philosophy of time in medicine. The problem of ethical time. In: Science without 
borders. Transactions of the International Academy of Science. H \&E, (2), 2005/2006, pp 104-115

Miah A (2003) Be very afraid: Cyborg Athletes, Transhuman Ideals and Posthumanity. J Evolution Technol 13(2)

Mooney P (2006) Hype and hope: a past and future perspective on new technologies for development. Development (49)16-22. [online]: http://www.palgrave-journals.com/development/journal/v49/n4/ full/1100305a.html

Morin E (2004) La Méthode, 6, Éthique, Seuil, Paris

O' Sullivan PE (1987) Environment science and environment philosophy. Int J Environ Studies 28:257-267

Peace Alliance Foundation (2005) The Mission of the Peace Alliance Foundation (home page). [online]: http://www.peacealliance found.org/content/blogsection/29/93/

Pilon AF (2003) Living better in a better world. The ecosystemic approach to quality of life. The Communication Initiative, 2003. [online] http://www.comminit.com/files/Pilon_\%20A_\%20F_\% 20Consolidated $\% 20$ Version[1].doc

Prigogine I (1980) From being to becoming. Freeman, San Francisco

Rapley J (2003) Human development: a conversation with Woodstock International Visiting Fellows; 2003. [online]: http://www. georgetown.edu/centers/woodstock/report/r-fea64a.htm

Riker J (2006) Ethics and contemporary life. Seminar, Colorado College, 2006. [online]: http://www.coloradocollege.edu/dept/ ED/TeacherScholarsProgramCoverPage 0607.pdf

Rockefeller Foundation (1974) Communication and social change network. Exploring the development of indicators derived from a social change and social movement perspective The Communication Initiative Forum. [online]: http://www.comminit.com/ socialchange/scfulleval/sld-1974.html

Ryan WF, SJ (1995) Culture, spirituality and economic developmentopening a dialogue. International Development Research Center, 1995. [online]: http://www.idrc.ca/en/ev-9384-201-1-DO_TOPIC. html

Shainberg D (1994) Vortices of thought in the implicate order. In: Hiley BJ, Peat FD (eds) Quantum implications. Essays in honour of David Bohm. Routledge \& Kegan Paul, London

Tsipko A (1985) Le socialisme; la vie de la societé et de l'homme. Ed. du Progrès, Moscow

Verburg RM, et Wiegel V (1997) On the compatibility of sustainability and economic growth. Environ Ethics 19:247-265

Wallner FE, Peschl FM (1999) Realism and general methodology phenomena. In: Cohen RS (ed) Realism and anti-Realism in the philosophy of science. Kluwer, New York

Wilson EO (2003) The Future of Life. Random House

Wood D (2000) Thinking against the grain. An interview by Darren Hutchinson, Fall 2000. [online]: http://www.vanderbilt.edu/AnS/ philosophy/faculty/wood_interview.html

Znaniecki F (1935) Ludzie terazniejsi a cywilizacja przyszlosci (The People of Today and the Civilization of Tomorrow), Ksiaznica Atlas, Lwow, Poland 